\section{JURNAL EKONOMI EFEKTIF}

ISSN : $2622-8882$, E-ISSN : 2622-9935

Jurnal Ekonomi Efektif, Vol. 1, No. 4, Juli 2019

@Prodi Manajemen Fakultas Ekonomi Universitas

Pamulang

\title{
PENGARUH PROMOSI TERHADAP KEPUTUSAN PEMBELIAN PADA PT. BOGA SEJAHTERA DI CIKARANG
}

\author{
Dedeh Kurniasih \\ STIE Primagraha, Serang, Banten, Indonesia \\ *toyang67@gmail.com
}

\begin{abstract}
ABSTRAK
Penelitian ini bertujuan untuk mengetahui pengaruh ekuitas merek terhadap keputusan pembelian pada PT. Surya Motor di Cikupa. Metode yang digunakan adalah explanatory research dengan sampel sebanyak 96 responden. Teknik analisis menggunakan analisis statistik dengan pengujian regresi, korelasi, determinasi dan uji hipotesis. Hasil penelitian ini variabel ekuitas merek diperoleh nilai rata-rata skor sebesar 3,410 dengan kriteria baik. Variabel keputusan pembelian diperoleh nilai rata-rata skor sebesar 3,815 dengan kriteria baik. Ekuitas merek berpengaruh positif dan signifikan terhadap keputusan pembelian dengan nilai persamaan regresi $\mathrm{Y}=9,123+0,851 \mathrm{X}$, dan nilai koefisien korelasi 0,756 atau memiliki tingkat hubungan yang kuat dengan nilai determinasi 57,2\%. Uji hipotesis diperoleh signifikansi 0,000 $<0,05$.
\end{abstract}

Kata Kunci: Ekuitas Merek, Keputusan Pembelian.

\section{ABSTRACT}

This study aims to determine the effect of brand equity on purchasing decisions at PT. Surya Motor in Cikupa. The method used is explanatory research with a sample of 96 respondents. The analysis technique uses statistical analysis with regression testing, correlation, determination and hypothesis testing. The results of this study, the brand equity variable obtained an average score of 3,410 with good criteria. The purchase decision variable obtained an average score of 3.815 with good criteria. Brand equity has a positive and significant effect on purchasing decisions with a regression equation value of $Y=9,123+$ $0.851 X$, and a correlation coefficient value of 0.756 or having a strong level of relationship with a determination value of $57.2 \%$. Hypothesis testing obtained a significance of 0.000 $<0.05$.

\section{Keywords: Brand Equity, Purchase Decision.}




\section{PENDAHULUAN}

\section{A. Latar Belakang Masalah}

Ketidakpastian adalah mutlak dalam lingkungan ekonomi bisnis yang sangat dinamis. Oleh karena itu, dalam era globalisasi seperti sekarang, perusahaan dituntut bersaing secara kompetitif dalam hal menciptakan dan mempertahankan konsumen (pelanggan) yang loyal. Salah satunya adalah melalui persaingan antar merek. Perusahaan menyadari merek menjadi faktor penting dalam persaingan dan menjadi asset perusahaan yang paling bernilai.

David A. Aaker menyebutkan model ekuitas merek terdiri dari 5 elemen, Keller (2008:670), yaitu: loyalitas merek (brand loyality), kesadran merek (brand awareness), persepsi kualitas (perceived quality), asosiasi merek (brand associations), dan aset-aset dari hak merek lain dari merek (other proprietary brand assets) karena tujuan dari penelitian ini adalah melihat konsep ekuitas merek dari perspektif pelanggan, sedangkan aset-aset hak milik lain dari merek (other proprietary brand assets) adalah komponen ekuitas merek yang lebih cenderung ditinjau dari perspektif perusahaan. Sehingga pada pembahasan elemen ekuitas merek dalam penelitian ini hanya terdiri dari 4 variabel tersebut diatas.

Loyalitas merek (brand loyalty) merupakan satu ukuran keterkaitan seorang pelanggan pada sebuah merek. Loyalitas merek didasarkan atas perilaku konsisten pelanggan untuk membeli sebuah merek sebagai bentuk proses pembelajaran pelanggan atas kemampuan merek memenuhi kebutuhannya. Selain sebagai bentuk perilaku pembelian yang konsisten, loyalitas merek juga merupakan bentuk sikap positif pelanggan dan komitmen pelanggan terhadap sebuah merek lainnya.

PT. Surya motor merupakan dealer resmi yang menjual sepeda motor merek Yahama dari berbagai type dan harga yang bervariasi. Disamping penjualan sepeda motor baru, juga melayani service bagi pelanggan. Seperti pada umumnya perusahaan jasa maupun proguk faktor merek produk juga menjadi salah satu aspek yang penting dalam pengambilan keputusan membeli atau tidaknya si konsumen. Oleh karenanya pengalaman yang dialami konsumen menjadi pertimbangan tersendiri.

Berdasarkan uraian tersebut, maka penulis tertarik untuk menulis penelitian ilmiah ini yang berjudul "Pengaruh Ekuitas Merek Terhadap Keputusan pembelian Sepeda Motor Yamaha Pada PT. Surya Motor"

B. Rumusan Masalah

1. Bagaimana ekuitas merek pada PT. Surya Motor di Cikupa?.

2. Bagaimana keputusan pembelian pada PT. Surya Motor di Cikupa ?.

3. Adakah pengaruh antara ekuitas merek terhadap keputusan pembelian pada PT. Surya Motor di Cikupa?.

\section{Tujuan Penelitian}

1. Untuk mengetahui kondisi ekuitas merek pada PT. Surya Motor di Cikupa.

2. Untuk mengetahui kondisi keputusan pembelian pada PT. Surya Motor di Cikupa.

3. Untuk mengetahui pengaruh antara ekuitas merek terhadap keputusan pembelian pada PT. Surya Motor di Cikupa.

\section{TINJAUAN PUSTAKA}

\section{Ekuitas Merek}

Ekuitas merek menurut Surachman (2016) dapat didefinisikan sebagai efek diferensial positif yang ditimbulkan oleh pengetahuan nama merek terhadap tanggapan pelanggan atas produk atau jasa. 


\section{Keputusan Pembelian}

Keputusan pembelian menurut Nugroho (2015), adalah proses pemecahan masalah oleh konsumen untuk membeli suatu produk, setelah mempertimbangkan berbagai macam aspek maupun alternatif yang melibatkan afeksi-afeksi maupun pengaruh-pengaruh, baik dari dalam dirinya (pengetahuan yang didapat sendiri) maupun dari lingkungan sekitarnya.

\section{METODE PENELITIAN}

\section{Populasi}

Populasi dalam penelitian ini berjumlah 96 responden PT. Surya Motor di Cikupa

\section{Sampel}

Teknik pengambilan sampling dalam penelitian ini adalah sampel jenuh, dimana semua anggota populasi dijadikan sebagai sampel. Dengan demikian sampel dalam penelitian ini sampel yang digunakan berjumlah 96 responden.

\section{Jenis Penelitian}

Jenis penelitian yang dipakai adalah asosiatif, dimana tujuannya adalah untuk mengetahui atau mencari keterhubungan antara variabel independen terhadap variabel dependennya

\section{Metode Analisis Data}

Dalam menganalisis data digunakan uji validitas, uji reliabilitas, analisis regresi linier sederhana, analisis koefisien korelasi, analisis koefisien determinasi dan pengujian hipotesis.

\section{HASIL PENELITIAN}

\section{Analisis Deskriptif}

Pada pengujian ini digunakan untuk mengetahui skor minimum dan maksimum skor tertinggi, ratting score dan standar deviasi dari masing-masing variabel. Adapun hasilnya sebagai berikut:

Tabel 1. Hasil Analisis Descriptive Statistics

\section{Descriptive Statistics}

\begin{tabular}{lr|r|r|r|r} 
& N & Minimum & Maximum & Mean & Std. Deviation \\
\hline Equitas Merek & 96 & 28 & 44 & 34.10 & 3.735 \\
\hline Keputusan Pembelian & 96 & 29 & 49 & 38.15 & 4.203 \\
\hline Valid N (listwise) & 96 & & & & \\
\hline
\end{tabular}

Ekuitas merek diperoleh varians minimum sebesar 28 dan varians maximum 44 dengan ratting score sebesar 3,410 dengan standar deviasi 3,735. Skor ini termasuk pada rentang sakala 3,40-4,19 dengan kriteria baik atau setuju.

Keputusan pembelian diperoleh varians minimum sebesar 29 dan varians maximum 49 dengan ratting score sebesar 3,815 dengan standar deviasi 4,203. Skor ini termasuk pada rentang sakala 3,40 - 4,19 dengan kriteria baik atau setuju.

\section{Analisis Verifikatif.}

Pada analisis ini dimaksudkan untuk mengetahui pengaruh variabel independen terhadap variabel dependen. Adapun hasil pengujian sebagai berikut:

\section{a. Analisis Regresi Linier Sederhana}

Uji regresi ini dimaksudkan untuk mengetahui perubahan variabel dependen jika variabel 
independen mengalami perubahan. Adapun hasil pengujiannya sebagai berikut:

Tabel 2. Hasil Pengujian Regresi Linier Sederhana

\begin{tabular}{|c|c|c|c|c|c|c|}
\hline \multicolumn{7}{|c|}{ Coefficients $^{a}$} \\
\hline \multirow{2}{*}{\multicolumn{2}{|c|}{ Model }} & \multicolumn{2}{|c|}{$\begin{array}{l}\text { Unstandardized } \\
\text { Coefficients }\end{array}$} & \multirow{2}{*}{$\begin{array}{c}\text { Standardized } \\
\text { Coefficients } \\
\text { Beta } \\
\end{array}$} & \multirow[b]{2}{*}{$\mathrm{t}$} & \multirow[b]{2}{*}{ Sig. } \\
\hline & & B & Std. Error & & & \\
\hline 1 & (Constant) & 9.123 & 2.606 & & 3.501 & .001 \\
\hline & Equitas Merek & .851 & .076 & .756 & 11.205 & .000 \\
\hline
\end{tabular}

a. Dependent Variable: Keputusan Pembelian

Berdasarkan hasil pengujian pada tabel di atas, diperoleh persamaan regresi $\mathrm{Y}=$ $9,123+0,851 X$. Dari persamaan tersebut dijelaskan sebagai berikut:

1) Konstanta sebesar 9,123 diartikan jika ekuitas merek tidak ada, maka telah terdapat nilai keputusan pembelian sebesar 9,123 point.

2) Koefisien regresi ekuitas merek sebesar 0,851, angka ini positif artinya setiap ada peningkatan ekuitas merek sebesar 0,851 point maka keputusan pembelian juga akan mengalami peningkatan sebesar 0,851 point.

\section{b. Analisis Koefisien Korelasi}

Analisis koefisien korelasi dimaksudkan untuk mengetahui tingkat kekuatan hubungan dari variabel independen terhadap variabel dependen. Adapun hasil pengujian sebagai berikut:

Tabel 3. Hasil Pengujian Koefisien Korelasi Ekuitas merek Terhadap Keputusan pembelian.

\begin{tabular}{|c|c|c|c|}
\hline \multicolumn{4}{|c|}{ Correlations $^{b}$} \\
\hline & & Equitas Merek & $\begin{array}{l}\text { Keputusan } \\
\text { Pembelian }\end{array}$ \\
\hline \multirow[t]{2}{*}{ Equitas Merek } & Pearson Correlation & 1 & $.756^{\star *}$ \\
\hline & Sig. (2-tailed) & & .000 \\
\hline \multirow[t]{2}{*}{ Keputusan Pembelian } & Pearson Correlation & $.756^{* *}$ & 1 \\
\hline & Sig. (2-tailed) & .000 & \\
\hline
\end{tabular}

Berdasarkan hasil pengujian diperoleh nilai korelasi sebesar 0,756 artinya ekuitas merek memiliki hubungan yang kuat terhadap keputusan pembelian.

\section{c. Analisis Koefisien Determinasi}

Analisis koefisien determinasi dimaksudkan untuk mengetahui besarnya persentase pengaruh dari variabel independen terhadap variabel dependen. Adapun hasil pengujian sebagai berikut:

Tabel 4. Hasil Pengujian Koefisien Determinasi Ekuitas merek Terhadap Keputusan pembelian.

\begin{tabular}{|c|c|c|c|c|}
\hline \multicolumn{5}{|c|}{ Model Summary } \\
\hline Model & $\mathrm{R}$ & R Square & $\begin{array}{l}\text { Adjusted R } \\
\text { Square }\end{array}$ & $\begin{array}{c}\text { Std. Error of the } \\
\text { Estimate }\end{array}$ \\
\hline 1 & $.756^{a}$ & .572 & .567 & 2.765 \\
\hline
\end{tabular}

a. Predictors: (Constant), Equitas Merek

Berdasarkan hasil pengujian diperoleh nilai determinasi sebesar 0,572 artinya ekuitas merek memiliki kontribusi pengaruh sebesar 57,2\% terhadap keputusan pembelian, sedangkan sisanya sebesar $42,8 \%$ dipengaruhi oleh faktor lain yang tidak dilakukan penelitian. 


\section{d. Uji Hipotesis}

Pengujian hipotesis dengan uji t digunakan untuk mengetahui hipotesis mana yang diterima.

Rumusan hipotesis: Terdapat pengaruh yang signifikan antara ekuitas merek terhadap keputusan pembelian.

Tabel 5. Hasil Uji Hipotesis Ekuitas merek Terhadap Keputusan pembelian.

\begin{tabular}{|c|c|c|c|c|c|c|}
\hline & & & efficients & & & \\
\hline & & $\begin{array}{r}\text { Unsta } \\
\text { Coe }\end{array}$ & $\begin{array}{l}\text { lardized } \\
\text { cients }\end{array}$ & $\begin{array}{l}\text { Standardized } \\
\text { Coefficients }\end{array}$ & & \\
\hline & & $\mathrm{B}$ & Std. Error & Beta & $\mathrm{t}$ & Sig. \\
\hline 1 & (Constant) & 9.123 & 2.606 & & 3.501 & .001 \\
\hline & Equitas Merek & .851 & .076 & .756 & 11.205 & .000 \\
\hline
\end{tabular}

a. Dependent Variable: Keputusan Pembelian

Berdasarkan hasil pengujian pada tabel di atas, diperoleh nilai $\mathrm{t}$ hitung $>\mathrm{t}$ tabel atau $(11,205>1,986)$, dengan demikian hipotesis yang diajukan bahwa terdapat pengaruh yang signifikan atara ekuitas merek terhadap keputusan pembelian diterima.

\section{Pembahasan Hasil Penelitian}

\section{Kondisi Jawaban Responden Variabel Ekuitas merek}

Berdasarkan jawaban responden, variabel ekuitas merek diperoleh ratting score sebesar 3,410 berada di rentang skala 3,40 - 4,19 dengan kriteria baik atau setuju.

\section{Kondisi Jawaban Responden Variabel Keputusan pembelian}

Berdasarkan jawaban responden, variabel keputusan pembelian diperoleh ratting score sebesar 3,815 berada di rentang skala 3,40-4,19 dengan kriteria baik atau setuju.

\section{Pengaruh Ekuitas merek Terhadap Keputusan pembelian}

Ekuitas merek berpengaruh signifikan terhadap keputusan pembelian dengan persamaan regresi $\mathrm{Y}=9,123+0,851 \mathrm{X}$, nilai korelasi sebesar 0,756 atau memiliki hubungan yang kuat dengan kontribusi pengaruh sebesar 57,2\%. Pengujian hipotesis diperoleh nilai t hitung $>\mathrm{t}$ tabel atau $(11,205>1,986)$. Dengan demikian hipotesis yang diajukan bahwa terdapat berpengaruh signifikan antara ekuitas merek terhadap keputusan pembelian diterima.

\section{KESIMPULAN DAN SARAN}

1. Kesimpulan

a. Variabel ekuitas merek diperoleh ratting score sebesar 3,410 berada di rentang skala 3,40 $-4,19$ dengan kriteria baik atau setuju.

b. Variabel keputusan pembelian diperoleh ratting score sebesar 3,815 berada di rentang skala 3,40-4,19 dengan kriteria baik atau setuju.

c. Ekuitas merek berpengaruh signifikan terhadap keputusan pembelian dengan persamaan regresi $\mathrm{Y}=9,123+0,851 \mathrm{X}$, nilai korelasi sebesar 0,756 atau kuat dan kontribusi pengaruh sebesar $57,2 \%$ sedangkan sisanya sebesar $42,8 \%$ dipengaruhi faktor lain. Uji hipotesis diperoleh nilai $t$ hitung $>t$ tabel atau $(11,205>1,986)$.

\section{Saran}

a. Sebaiknya untuk Ekuitas Merek pada PT. Surya Motor lebih memfokuskan tampilan 
desain yang dijual dan lebih memberikan kualitas yang lebih baik.

b. Meskipun sebagian besar responden merasa puas atas Ekuitas Merek pada PT. Surya Motor, namun masih ada skor atau penilaian yang rendah yaitu karyawan masih belum memberikan informasi yang akurat kepada konsumen, karyawan masih kurang menguasai produk knowledge. Pada skor-skor ini perlu dilakukan langkah-langkah perbaikan sehingga diharapkan dapat meningkatnya keputusan pembelian secara menyeluruh.

\section{DAFTAR PUSTAKA}

Aaker, A. David. "Manajemen Ekuitas Merek Alih bahasa oleh Aris Ananda", Cikupa: Mitra Utama. 2008.

Agus Purwanto, Erwan dan Dyah Ratih Sulistyastuti, "Metode Penelitian Kuantitatif, Untuk Administrasi Publik, Dan Masalah-masalah Sosial”, Yogyakarta: Gaya Media. 2007.

Ahidin, Umar, "Riset pemasaran dan bisnis", Cikupa: Gramedia Pustaka Utama, 2010.

Ahmad, Subagio, "Marketing In Business", Cikupa: Mitra Wacana Medi. 2010.

Algifari. (2015). "Analisis Regresi untuk Bisnis dan Ekonomi”. Yogyakarta: BPFE.

Alma, Buchari. "Manajemen Pemasaran dan Pemasaran Jasa", Bandung: Alfabeta. 2013.

Arikunto, Suharsimi (2014). "Prosedur Penelitian Suatu Pendekatan Praktek". Cikupa: Rineka Cipta.

Arikunto. "Prosedur Penelitian: Suatu Pendekatan Praktek", Cikupa: Rineka Cipta. 2010.

Bashu Swastha dan T. Handoko (2015) Manajemen Pemasaran Moderen, Yogyakarta: BPFE.

Basu Swastha dan Irawan, “Asas-asas Marketing”, Yogyakarta: Liberty. 2005,

Basu Swastha Dharmmesta. (2014). Manajemen Pemasaran. BPFE: Yogyakarta. Buchari

Alma. 2014. Manajemen pemasaran dan Pemasaran Jasa. Edisi Revisi.

Bilson Simamora (2016) Panduan Riset Prilaku Konsumen, Cikupa: PT. Gramedia Pustaka.

Brown,H. Douglas, "Teaching by Principle An Interactive Approach to Language Pedagogy", San Francisco: Longman. 2001.

Deliyanti Oentoro, “Manajemen Pemasaran Modern", Yogyakarta: LakBang PRESSindo. 2010.

Erlangga, H. (2018). Spirit Pengembangan Kewirausahaan Di Perguruan Tinggi. Paradigma POLISTAAT: Jurnal Ilmu Sosial dan Ilmu Politik, 1(2), 102-127.

Fandy Tjiptono (2017), Serivce Quality and Satisfiation. Cikupa: Edisi tiga. Andi.

Freddy Rangkuti (2016) Strategi Promosi Yang Kreatif, Edisi Pertama, Cetakan Pertama Cikupa: Gramedia Pustaka Utama.

George Terry R \& Rue, Leslie W. Rue (2016) Dasar-Dasar Manajemen, Cikupa Bumi Aksara. Ilham, D. (2014). Implementasi Nilai-Nilai Keagamaan pada Mata Pelajaran Umum dalam

Upaya Peningkatan Akhlak Peserta Didik di MAN Malili Kabupaten Luwu

Timur (Doctoral dissertation, STAIN/IAIN Palopo).

Ilham, D. (2019). Implementing Local Wisdom Values in Bride and Groom Course at KUA

Bara SubDistrict, Palopo City. Jurnal Konsepsi, 8(1), 1-9.

Ilham, D. (2019). Menggagas Pendidikan Nilai dalam Sistem Pendidikan

Nasional. Didaktika: Jurnal Kependidikan, 8(3), 109-122.

Imam Ghozali (2017). “Aplikasi Analisis Multivariate Dengan Program SPSS”. Edisi Kelima. Semarang: Badan Penerbit Undip.

J. Setiadi, Nugroho, SE., MM., "Perilaku Konsumen Konsep dan Implikasi untuk Strategi dan Penelitian Pemasaran", Cikupa: Kencana. 2003.

Kotler dan Amstrong (2017), Prinsip-prinsip Pemasaran. Edisi Kedua Belas”. Jilid Satu. 
Cikupa: Erlangga.

Lamb, Charles. W, Et al, "Pemasaran Buku", I. Edisi I. Cikupa : Salemba Empat. 2011.

Lupiyoadi (2016) Manajemen Pemasaran Jasa, Edisi 4, Cikupa: Salemba Empat.

Mani, J. (2017). Pengaruh Persepsi Merek Dan Kualitas Pelayanan Terhadap Kepuasan Pelanggan (Studi Kasus Pada PT. Bisma Narendra Di Cikupa). Jurnal Mandiri, 1(2), 187 206.

Mani, J. (2018). Pengaruh Peran Nilai Pelanggan Dan Citra Merek Terhadap Kinerja Pemasaran. Jurnal Mandiri, 2(2), 263-280.

Mulyadi, "Manajemen pemasaran", Edisi Ketiga, Cetakan Ketiga, Penerbit Cikupa: Salemba Empat. 2001.

Nurhayati, N. I. D. N., Hindarsah, I., Sos, S., Erlangga, H., Sos, S., \& Maun Jamaludin, I. (2018). Pelatihan Pembukuan Di UKM Sumpia Chantika Dewi Cimindi Cimahi. Laporan Program Kepakaran Fisip Unpas Pengabdian Kepada Masyarakat Tahun Akademik 2016/2017, 1-22.

Nurjaya, N., \& Maulida, N. (2018). Tingkat Kesukaan Konsumen Pada Atribut Beras Pandanwangi Murni Cianjur. AGROSCIENCE (AGSCI), 8(1), 107-121.

Philip Kotler (2017) Manajemen Pemasaran, Edisi Keempat Belas, Cikupa: PT. Indeks.

Rangkuti, Freddy, “Analisis SWOT Teknik Membedah Kasus Bisnis", Cikupa : Penerbit PT. Gramedia Pustaka Utama . 2014.

Rao, Purba, (2012). "Measuring Consumer Perceptions Through Factor Analysis", The Asian. S. A. Surachman, "Dasar-Dasar Manajemen Merek", Malang: Bayumedia Publishing. 2008.

Santoso, Singgih (2015). "Menguasai Statistik Multivariat”. Cikupa: PT Elex Media Komputindo.

Setiadi, Nugroho J, “Perilaku Konsumen”, Cikupa: Kencana. 2010

Siregar, Sofyan, "Statistika Deskriptif untuk penelitian", Cikupa: Rajawali Pers. 2010.

Sudjana (2014) "Metode Statistika”, Bandung: Tarsido.

Sugiyono (2017), "Metode Penelitian Administrasi : dilengkapi dengan Metode $R \& D$ ". Bandung: Alfabeta.

Suhartanto (2014). "Metode Riset Pemasaran". Bandung: Alfabeta

Supardi. “Manajemen pemasaran”, Cikupa: Raja Grafindo Persada. 2014. 